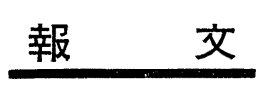

\title{
表面改質したカーボンブラックによる 有機物質の吸着特性
}

\author{
浅 川丈夫*・荻 野 圭 三*,** \\ * 東京理科大学理工学部 (千葉県野田市山崎 2641) \\ ** 東京理科大学界面科学研究所 (東京都新宿区神楽坂 1-3)
}

\section{Adsorption of Organic Compounds on Surface-modified Carbon Black}

\author{
Takeo AsAKAwA* and Keizo OGINo*,** \\ * Faculty of Science and Technology, Science University of \\ Tokyo (2641, Yamazaki, Noda-shi, Chiba) \\ ** Institute of Colloid and Interface Science, Science Uni= \\ versity of Tokyo (1-3, Kagurazaka, Shinjuku-ku, Tokyo)
}

\begin{abstract}
The adsorption equilibria of benzene derivatives (phenol, benzoic acid, nitrobenzene, and ani= line), 1-hexanol, 1-butanol, 1-heptanoic acid, and valeric acid on carbon black in aqueous solutions were studied. The carbon black used as the adsorbent was Electronic Conductive Carbon Black (Lion Akzo Co.) treated with nitric acid (B) or hydrogen (C). The surface acidity of carbon black $\mathrm{B}$ was large, but that of carbon black $\mathrm{C}$, small. The adsorption isotherms were in good agreement with the Freundlich-type isotherm. The amounts of organic compounds adsorbed increased with decreasing solubility in water. The amount of phenol adsorbed was very large and its solubility, large. To investigate the influence of the ionization of phenol, the amounts of phenol, benzoic acid, and aniline adsorbed on modified carbon blacks were measured for their solutions varying widely in $\mathrm{pH}$. The amounts of phenol and benzoic acid adsorbed on carbon black $\mathrm{C}$ decreased with increasing $\mathrm{pH}$, but the amount of aniline adsorbed onto it decreased with decreasing $\mathrm{pH}$. Thus, the amount of phenol, benzoic acid, and aniline adsorbed decrease with an increase in the amount of adsorbate ionized. The pKa value of phenol was larger than those of other organic compounds. Consequently, it is thought that phenol is adsorbed specifically owing to its large pKa. The adsorption character of an organic compound can be predicted on the basis of its solubility and pKa.
\end{abstract}

\section{1 緒 言}

近年では都市人口の著しい増加と産業活動の挔大によ って，好気性微生物が分解できない新しい廃衰物，生物 活動を妨害する有機物質, 富栄養化などの新しい污染が 入り込み，二次処理ではもはや廃棄物の処理は不充分と なり，そのため高度処理の必要が叫ばれている1)。高度 処理には，個々の条件に応じて種々の組み合わせがある が，その大部分には，活性炭などの吸着剤を用いた吸着 工程が入っている(1) 。

著者らは, 活性炭にとってかわる吸着剤として, 表面 積の非常に大きい特殊カーボンブラックに対するフェノ ールの吸着性に及ぼすカーボンブラックの表面化学構造
の影響を検討してきた ${ }^{5,6)}$ 。そして，カーボンブラック を水素処理することによって，カーボンブラック表面を 疎水化すると, フェノールの吸着量が増加することがわ かった。しかし，実排水中には数多くの有機物質が含ま れており，それらが吸着処理にどのような影響を及ぼす かを調べることは重要である。

そこで本研究では, 種々の有機物質について, 前報と 同様に，吸着実験を行ったところ，フェノールだけが， 特異的な吸着性を示したので, 主としてこの特異性につ いて検討した。

\section{2 実験}

\section{$2 \cdot 1$ 実 験 試 料}


原試料のカーボンブラックは, ライオン・アクゾ社か ら提供された導電性カーボンブラックを用いた。

被吸着質法,フェノール, 安息香酸, ニトロベンゼ ン, アニリン，1ーヘキサノール，1-ブタノール，ヘプタ ン酸及び吉草酸を用いた。これらは，いずれも和光純薬 工業（株）をそのまま使用した。

\section{$2 \cdot 2$ 実験操作}

\section{$2 \cdot 2 \cdot 1$ カーボンブラックの表面改質}

カーボンブラック A (未改質カーボンブラック)：原 試料を粉砕して $60^{\circ} \mathrm{C} て ゙ ~ 6 \mathrm{~h}$ 真空乾燥した。

カーボンブラック B : 原試料を $13.2 \mathrm{~N}$ の硝酸を用い て, その沸点に扔いて $1 \mathrm{~h}$ 処理し, 次に惹沸熱水処理し て沪別し, その沪液の伝導度が 2 回蒸留水の伝導度 $(2 \times$ $\left.10^{-6} \mho / \mathrm{cm}\right)$ とほほ同じになるまで煮沸熱水処理を繰り 返した後, $120^{\circ} \mathrm{C} て ゙ 18 \mathrm{~h}$ 乾燥させた。その後, 粉砕し て $60^{\circ} \mathrm{C}$ で $6 \mathrm{~h}$ 真空乾燥した。

カーボンブラック $\mathrm{C}$ : 原試料を $1000^{\circ} \mathrm{C}$ で $1 \mathrm{~h}$ 真空排 気してから， $1000^{\circ} \mathrm{C}$ で 500 Torr の水素を $10 \mathrm{~min}$ 導 入, $5 \mathrm{~min}$ 排気を 4 回繰り返し, 500 Torr の水素雾囲 気中で自然放冷させた後, 粉砕した。

これらのカーボンブラックの性質を Table-1 に示 す。

\section{$2 \cdot 2 \cdot 2$ 平衡吸着実験}

平衡吸着実験泣，前報鸟と同様な方法で行った。 $2 \cdot 2 \cdot 3 \mathrm{pH}$ の影響

$100 \mathrm{ml}$ の共栓付き三角フラスコに $0.6 \mathrm{~g} / \mathrm{l}$ のカーボン ブラックをはかりとり，これに $\mathrm{HCl}$ または $\mathrm{NaOH}$ で $\mathrm{pH}$ を調整した $100 \mathrm{mg} / l$ の濃度の有機物質の水溶液 50 $\mathrm{ml}$ を加え $25^{\circ} \mathrm{C}$ で $24 \mathrm{~h}$ 振とう後, 東洋滤紙 $5 \mathrm{c}$ を用 いて吸引沪過し, 沪液の濃度を全有機炭素量計（島津 TOC-10 B) 用いて求めた。空試験も同様にして行 い, その濃度差から吸着量を求めた。そして, 平衡吸着 時の $\mathrm{pH}$ と単位カーボンブラック量当たりの吸着量とを 求めた。なお $\mathrm{pH}$ の測定には Corning $\mathrm{pH}$ meter 130 を用いた。

Table-1 Properties of surface modified carbon black samples.

\begin{tabular}{c|c|c|c|c|c}
\hline $\begin{array}{l}\text { Carbon } \\
\text { black }\end{array}$ & $\begin{array}{c}\text { Surface } \\
\text { treatment }\end{array}$ & $\begin{array}{c}\text { Specific } \\
\text { surface } \\
\text { area }^{\mathrm{a})} \\
\left(\mathrm{m}^{2} / \mathrm{g}\right)\end{array}$ & $\begin{array}{c}\text { Pore } \\
\text { volume }\end{array}$ & $\begin{array}{c}\left.\mathrm{Ash}^{\mathrm{c}}\right) \\
(\mathrm{ml} / \mathrm{g})\end{array}$ & $\begin{array}{c}\text { Total } \\
\text { surface } \\
\text { acidity }^{\mathrm{d})} \\
(\mathrm{meq} / \mathrm{g})\end{array}$ \\
\hline $\mathrm{A}$ & Unmodified & 886 & 0.855 & 0.20 & 0.07 \\
$\mathrm{~B}$ & $13.2 \mathrm{~N} \mathrm{HNO}_{3}$ & 670 & 0.562 & 0.02 & 0.89 \\
$\mathrm{C}$ & $\mathrm{H}_{2}$ & 851 & 0.863 & 0.25 & 0.05 \\
\hline
\end{tabular}

a) By $\mathrm{N}_{2}$, BET method.

b) Cranston-Inkley method, from 10 to $300 \AA$ pore diameter.

c) The ash content was determined with a porcelain crucible in the atmosphere.

d) By Boehm method.

\section{3 結果及び考察}

\section{$3 \cdot 1$ 末改質カーボンブラックによる吸着特性}

カーボンブラック A (未改質カーボンブラック) に対 するフェノール, 安息香酸, ニトロベンゼン, アニリ ン，1一ヘキサノール，ヘプタン酸，1-ブタノール及び吉 草酸の吸着等温線を Fig.-1 に示す。Fig.-1 に示した ように，すべての有機物質に対し，平衡濃度と吸着量と の関係が両対数で直線関係になったので，これらの吸着 等温線流すべて Freundlich 型の吸着等温式で整理でき た。これらの有機物質の Freundlich 定数を Table-2 に示す。Fig.-1 及び Table-2 より，カーボンブラッ クへの吸着量は, 被吸着質の官能基の相違によって

$$
-\mathrm{NO}_{2}>-\mathrm{COOH}>-\mathrm{OH}>-\mathrm{NH}_{2}
$$

の順に小となった。芳香族化合物と脂肪族化合物の吸着 量を比較すると, $-\mathrm{COOH}$ 基, $-\mathrm{OH}$ 基ともに脂肪族化 合物の方が吸着量注多い。炭素鎖長は長い方が吸着量が 多いことがわかった。

水溶液中からの有機物質の固体表面への吸着現象にお いては，有機物質・水・固体表面の三者間の親和性が問 題となる。ここでは, このうち水・有機物質の親和性が 問題となり，その親和性の指標の一つとして溶解度を考

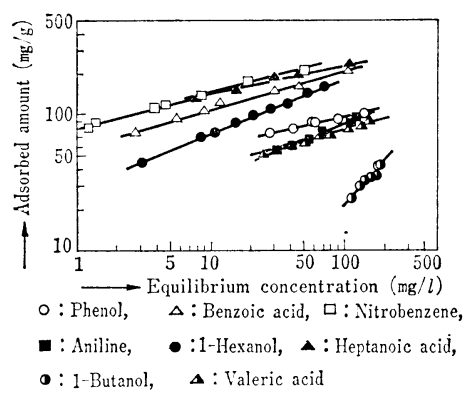

Fig.-1 Adsorption isotherms of organic compounds on carbon black $\mathrm{A}$ in aqueous solution at $25^{\circ} \mathrm{C}$.

Table-2 Freundlich constants of organic compounds on carbon black $\mathrm{A}$.

\begin{tabular}{l|r|r|r}
\hline \multirow{2}{*}{ Organic compound } & \multirow{2}{*}{$\begin{array}{c}\text { Molecular } \\
\text { weight }\end{array}$} & \multicolumn{2}{|c}{ Freundlich constant } \\
\cline { 3 - 4 } & & $k(\mathrm{mg} / \mathrm{g})$ & \multicolumn{1}{c}{$1 / n$} \\
\hline Phenol & 94.11 & 35.6 & 0.217 \\
Benzoic acid & 122.12 & 43.5 & 0.349 \\
Nitrobenzene & 123.11 & 82.2 & 0.255 \\
Aniline & 93.13 & 13.1 & 0.413 \\
1-Hexanol & 102.18 & 28.5 & 0.413 \\
Heptanoic acid & 130.19 & 83.9 & 0.229 \\
1-Butanol & 74.12 & 0.1 & 1.184 \\
Valeric acid & 102.13 & 19.5 & 0.306 \\
\hline
\end{tabular}

a) $\mathrm{X} / \mathrm{M}=k \cdot C^{1 / n}$ 


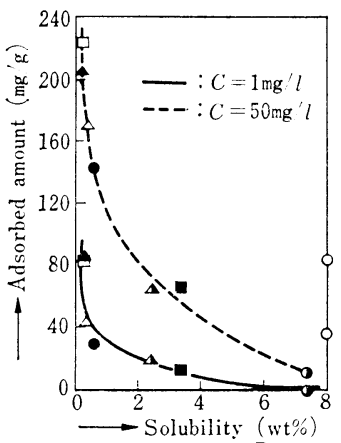
$0:$ Phenol,
$\triangle$ : Benzoic acid,
$\square:$ Nitrobenzene,
- : Aniline,
- : 1-Hexanol,
$\Delta$ : Heptanoic acid,
- : i-Butanol;
$\Delta$ : Valeric acid

Fig.-2 Relationship between the adsorbed amount on carbon black $\mathrm{A}$ and the solubility of the organic compounds in water.

えることができる。Fig.-2 に吸着量と水に対する溶解 度7),8) との関係を示す。吸着量の大小を判断する指標と しては, Freundlich 定数 $k$ (平衡濃度 $C=1 \mathrm{mg} / l$ 時の 吸着量）及び本実験の平衡濃度範囲の関係から $C=50$ $\mathrm{mg} / l$ 時の吸着量とを用いた。一般に分子量が異なる 2 種以上の物質の吸着剤に対する被吸着能を比較する場 合, 吸着量を重量単位で表示するときとモル単位で表示 するときでは吸着量の大小が逆転する場合がある9 。ふ つう廃水処理の基本データは重量単位で整理されてお り, 重量で吸着量の多い物質ほど吸着されやすいとして いる゚。。また, 吸着剤の特性が, その細孔構造に大きく 依存することから, 被吸着質の容積が, 吸着データを取 り扱う場合, 問題となる。被吸着質の容積はその重量と も関係があるため, 吸着量の大小を議論する場合, 吸着 量を重量で表示すると便利である。しかし，モル表示も 重要な知見を与えてくれるため, 吸着機構の詳細な考察 をする場合には両表示による考察が必要である9。Fig.-

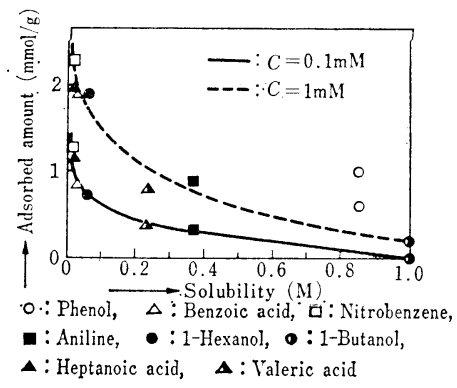

Fig.-3 Relationship between the adsorbed amount on carbon black $\mathrm{A}$ and the solubility of the organic com $=$ pounds in water.
3 にモル単位で示した吸着量と水に対する溶解度との関 係を示す。Fig.-3 での吸着量の大小を判断する指標と しては，実験の平衡濃度範囲より， $C=0.1 \mathrm{mM}$ 及び $C=1 \mathrm{mM}$ 時の吸着量とを用いた。Fig. -2 及び Fig.-3 より吸着量は, 被吸着質の水に対する溶解度が増加する につれて著しく減少するが，フェノールだけが異常的に 吸着量が多いことがわかった。これらの結果は, 著者ら が活性炭に対して行ったときの結果 ${ }^{10)}$ と同じ傾向を示 す。

活性炭, カーボンブラックなどの炭素は無定形炭素と 呼ばれ，微細な黒鉛結晶子から成るが，結晶子の大小， 結晶子の相互の配向がそれぞれ異なり, 細孔分布がそれ ぞれ異なる ${ }^{11)}$ 。前報 ${ }^{10)}$ で示した活性炭は, 比表面積が, $961 \mathrm{~m}^{2} / \mathrm{g}$, 細孔容積が $0.324 \mathrm{ml} / \mathrm{g}$ であり, 本報で用い たカーボンブラックより微小径の細孔を多量に持つ。し かしながら，上运のように同様な傾向を示すことから， フェノールの特異的な吸着は, 吸着剂の細孔構造の影響 によるものでないことがわかった。

\section{2 表面改質カーボンブラックへの吸着特性}

カーボンブラックへの吸着特性に影響を及ぼす要因と して, カーボンブラックの細孔構造のほふにカーボンブ ラックの表面化学構造が考えられる ンブラックの表面官能基とフェノールとの相互作用を検 討するために,カーボンブラックを表面改質し,そのカー ボンブラックを用いて種々の有機物質の吸着実験を行っ た。Fig.-4 に表面改質カーボンブラックヘの吸着量と 被吸着質の水に対する溶解度との関係を示す。カーボン ブラック Bは硝酸酸化したものであり，カーボンブラッ クCは水素により表面を踈水化したものである。Fig.-3 及び Fig.-4より明らかなように, どの被吸着質も表面 酸性度の大きいカーボンブラックBへの吸着量は少な く, 表面酸性度の小さいカーボンブラックCへの吸着量 は多くなった。これは, 単位表面積当たりの吸着量に換 算しても同様な傾向を示す。以上より，カーボンブラッ クの表面官能基とフェノールとの特異的ふ相互作用はな

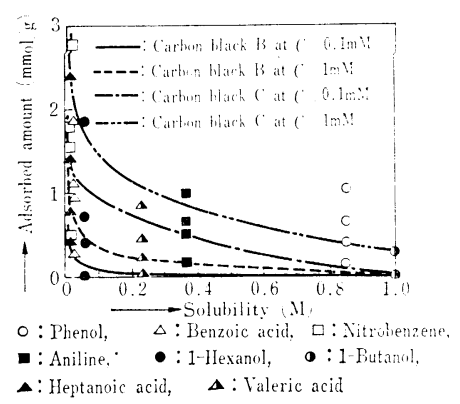

Fig.-4 Relationship between the adsorbed amount on modified carbon blacks and the solubility of the organic compounds in water. 
いと考えられる。また，Fig.-4 より，表面改質カーボ ンブラックも被吸着質の水に対する溶解度が增加するに つれて吸着量は著しく減少したが，フェノールだけが特 異的に吸着量が多いことがわかった。

\section{$3 \cdot 3 \mathrm{pH}$ の影響}

種々の $\mathrm{pH}$ の水溶液からの, カーボンブラックに対 する有機物質の吸着量から，カーボンブラックへの吸着 に及ぼ寸被吸着質のイオン化の影響を検討した。Fig.-5 及び Fig.-6に，カーボンブラックB及びCへの有機物 質の吸着に対する水溶液の $\mathrm{pH}$ の影響を示す。Fig.-5 より明らかなように，塩基性側ではすべての有機物質の 吸着量注減少する。こ机汶, Fig. -6 に示した水素処理 カーボンブラックの強塩基性でのアニリンの吸着量が減 少しないことにより，カーボンブラック表面に存在する 酸性の表面官能基の影響によるものと考えられる。カー

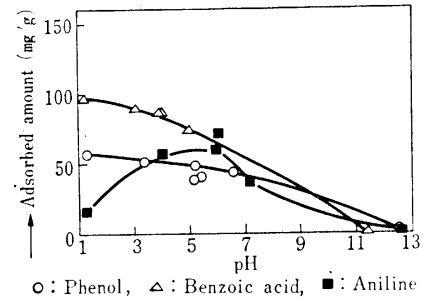

Fig. -5 Effect of $\mathrm{pH}$ on the adsorption of organic compounds on carbon black B.

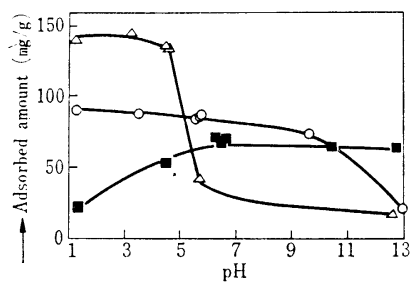

$\circ:$ Phenol, $\triangle:$ Benzoic acid, $\bullet$ : Aniline

Fig.-6 Effect of $\mathrm{pH}$ on the adsorption of organic compounds on carbon black $\mathrm{C}$.
ボンブラック表面に存在するカルボキシル基やフェノー ル性ヒドロキシル基などの酸性表面官能基注, 水溶液の $\mathrm{pH}$ が高くなると解離してアニオン型になると考えられ る $^{9,10)}$ 。解離してアニオン型になった表面官能基は, 解 離しない場合より多くの水分子との間に強い相互作用が 働き，表面官能基の周囲は多くの水分子によって占为ら れることになり, 表面官能基が解離しない場合よりカー ボンブラック表面に有機物質が吸着することを妨害する

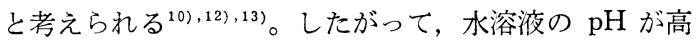
くなるにつれてカーボンブラック Bへの吸着量が減少し たものと思われる。

しかし，Fig.-6 のフェノール及び安息香酸の吸着量 が強塩基性側で減少した原因は, 使用したカーボンブラ ックが表面官能基を除去した水素処理カーボンブラック であること，及び同じ強塩基性でアニリンの吸着量汶減 少しなかったことより，カーボンブラックの表面官能基 以外のものによる影響と考えられる。また，Fig.-6よ り, 強酸性でアニリンの吸着量だけが著しく減少したこ とにより，アニリンは強酸性側で $\mathrm{C}_{6} \mathrm{H}_{5} \mathrm{NH}_{3} \oplus$ のイオン に, フェノール及び安息香酸は強塩基性側でそれぞれ $\mathrm{C}_{6} \mathrm{H}_{5} \mathrm{O} \ominus$ 及び $\mathrm{C}_{6} \mathrm{H}_{5} \mathrm{COO} \ominus$ のイオンにイオン化したため 吸着量が減少したものと考えら机る。すなわち，同じ被 吸着質でもイオン化すると，その吸着量沙減少するもの と考えられる。

\section{4 イオン化の影響}

Fig.-6より明らかなように, フェノールの吸着量は 安息香酸の場合より水溶液がかなり強塩基性にならない と減少しないこと，及び Table-3 に示したようにフェ ノールの $\mathrm{pKa}^{14)}$ だけが著しく大きい值であることによ り，フェノールは水汇対する溶解度が大きいのにもかか わらず，水中ではイオン化しにくいものと思われる。

浦野 ${ }^{15)}$ は，水溶液また海基性水溶液からの活性炭 及び高分子吸着剂への種々の芳香族化合物の吸着実験上 り, 弱酸性電解質の吸着量は, それがイオン化すると減 少することを見いだした。すなわち吸着性を判断する指 標として, 溶解度のほかにイオン化の影響を考える必要

Table-3 Properties of the organic compound samples at $25^{\circ} \mathrm{C}$.

\begin{tabular}{|c|c|c|c|c|c|c|}
\hline \multirow{2}{*}{ Organic compound } & \multirow{2}{*}{$\begin{array}{l}\text { Solubility } \\
s(\text { wt } \%)\end{array}$} & \multirow{2}{*}{$\mathrm{pK}_{\mathrm{a}}$} & \multicolumn{2}{|c|}{$[\mathrm{HA}]$} & \multicolumn{2}{|c|}{$s /[\mathrm{HA}]$} \\
\hline & & & $\begin{array}{c}C_{a}=1 \mathrm{mg} / \mathrm{l} \\
(\mathrm{M})\end{array}$ & $\begin{array}{c}C_{a}=0.1 \mathrm{mM} \\
(\mathrm{M})\end{array}$ & $C_{a}=1 \mathrm{mg} / \mathrm{l}$ & $C_{a}=0.1 \mathrm{mM}$ \\
\hline Phenol & 8.0 & 9.89 & $1.05 \times 10^{-5}$ & $9.99 \times 10^{-5}$ & $8.1 \times 10^{4}$ & $8.5 \times 10^{3}$ \\
\hline Benzoic acid & 0.34 & 4.214 & $8.76 \times 10^{-7}$ & $4.66 \times 10^{-5}$ & $3.2 \times 10^{4}$ & $6.0 \times 10^{\varepsilon}$ \\
\hline Heptanoic acid & 0.24 & 4.89 & $2.27 \times 10^{-6}$ & $7.00 \times 10^{-5}$ & $8.1 \times 10^{3}$ & $2.6 \times 10^{2}$ \\
\hline \multirow[t]{3}{*}{ Valeric acid } & \multirow[t]{3}{*}{2.4} & 4.84 & $3.11 \times 10^{-6}$ & $6.85 \times 10^{-5}$ & $7.6 \times 10^{4}$ & $3.4 \times 10^{3}$ \\
\hline & & $\mathrm{pK}_{\mathrm{b}}$ & \multicolumn{2}{|c|}{$\left[\mathrm{C}_{6} \mathrm{H}_{5} \mathrm{NH}_{2}\right]$} & \multicolumn{2}{|c|}{$s /\left[\mathrm{C}_{6} \mathrm{H}_{5} \mathrm{NH}_{2}\right]$} \\
\hline & & & $\begin{array}{c}C_{a}=1 \mathrm{mg} / l \\
(\mathrm{M})\end{array}$ & $\begin{array}{c}C_{a}=0.1 \mathrm{mM} \\
(\mathrm{M})\end{array}$ & $C_{a}=1 \mathrm{mg} / l$ & $C_{a}=0.1 \mathrm{mM}$ \\
\hline Aniline & 3.4 & 4.596 & $2.61 \times 10^{-6}$ & $6.08 \times 10^{-5}$ & $1.4 \times 10^{5}$ & $6.0 \times 10^{3}$ \\
\hline
\end{tabular}


があると思われる。

一般に, 弱電解質 HA は水中で次のように電離する。

$$
\mathrm{HA} \rightleftharpoons \mathrm{H}^{\oplus}+\mathrm{A}^{\ominus}
$$$$
\text { (アニリンの場合 : } \mathrm{RNH}_{2}+\mathrm{H} \oplus \rightleftharpoons \mathrm{RNH}_{3} \oplus \text { ) }
$$

すなわち, 水溶液中にはイオン化したものと分子状溶解 したものが共存する。Fig. -6 より，完全にイオン化し た弱電解質の吸着量は少なく，イオン化すると吸着性が 低下すると考えられる。そこで, 吸着は, 分子状溶解し たものが支配的であると考えられる。 $C_{a}$ を酸の濃度, いを電離度とすれば, 分子状溶解したものとイオン化し たものの濃度は，それぞれ

$$
\begin{aligned}
& {[\mathrm{HA}]=(1-\alpha) C_{a}} \\
& {[\mathrm{H} \oplus]=[\mathrm{A} \ominus]=\alpha C_{a}}
\end{aligned}
$$

で与えられる。つぎに, 上の化学平衡に質量作用の法則 を適用すれば, 電離定数 $K_{a}$ は,

$$
K_{a}=\frac{\left[\mathrm{H}^{\oplus}\right][\mathrm{A} \Theta]}{[\mathrm{HA}]}=\frac{\alpha^{2} C_{a}}{1-\alpha}
$$

となる。ここで, 平衡濃度が $1 \mathrm{mg} / l$ 及び $0.1 \mathrm{mM}$ の時 の有機物質の吸着性を検討するために, $1 \mathrm{mg} / l$ 及び 0.1 $\mathrm{mM}$ 中の有機物質の分子状溶解したものの濃度 [HA] を求めた。その結果を Table-3 に示す。溶解度 $s$ 洋前 述したように水と被吸着質である有機物質との親和性を 表す指標であり，同一種の吸着剤への吸着の場合，この 值が吸着性を表す指標となる。しかしながら，有機物質 の吸着性は，それがイオンに状態変化しても低下するの で，イオン化による影響も考えなければならない。そこ でイオン化による影響を近似させるために，単位 [HA] 当たりの溶解度, すなわち $s /[\mathrm{HA}]$ を吸着性を表す指 標とし，それと吸着量との関係を Fig.-7 及び Fig.-8

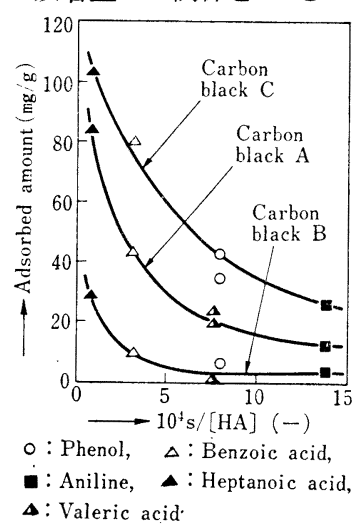

Fig. -7 The adsorbed amount at $C=1$ $\mathrm{mg} / l$ plotted versus $s /[\mathrm{HA}]$ for all modified carbon black samples.

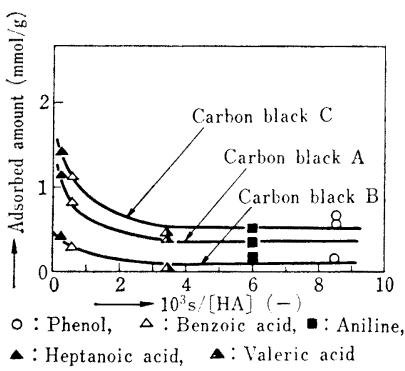

Fig.-8 The adsorbed amount at $C=0.1$ $\mathrm{mM}$ plotted versus $s /[\mathrm{HA}]$ for all modified carbon black samples.

に示す。なお $s /[\mathrm{HA}]$ の結果は Table-3 に示亦。

Fig.-7 及び Fig.-8より，s/[HA] の增加とともに吸 着量が減少することがわかる。したがって, フェノール は水に対する溶解度が大きいにもかかわらず, その水溶 液が強塩基性以外, ほとんどフェノールは分子状溶解で あるため, カーボンブラックに対して特異的な吸着性を 示したものと考えられる。

以上より，有機物質の吸着性を判断する指標として， 溶解度の外にイオン化の影響を考える必要があり，溶解 度と $\mathrm{pK}_{\mathrm{a}}$ により, 有機物質の吸着性が評価できると思 われる。

本研究の一部は文部省環境科学特別研究補助金沉る。付婄 して謝意を表す。

(昭和 59 年 12 月 3 日受理)

\section{文献}

1) 用水廃水便覧螎集委員会編, “用水廃水便覧” 丸善 (1973)

2）北川睦夫，四国工研会報，27，46 (1976)

3) 古藤 真, 天野正武, 千葉善陸, 中井敏博, 水処理技術, 20, 733 (1979)

4) 浦野紘平, 有合化，33，333 (1975)

5) T. Asakawa, K. Ogino, J. Colloid Interface Sci., 102, 348 (1984)

6) T. Asakawa, K. Ogino, K. Yamabe, Bull. Chem. Soc. Jpn., 58, 2009 (1985)

7）浅原照三, “溶荗ハンドブック”, 講談社 (1976)

8）日本化学会編, “化学便覧基礎編”, 丸善 (1966) p. 672

9) 安部郁夫, 林 勝己, 北川睦夫, 油化学, 25, 145 (1976)

10）浅川丈夫, 荻野圭三, 油化学, 33, 384 (1984)

11）炭素材料学会編，“活性炭 基礎と応用”, 講談社サイエン ティフィク (1978) p. 4, p. 19

12）荻野圭三, 浅川丈夫, 山边 潔, 高橋 浩, 油化学, 31 , 159 (1982)

13）浅川丈夫, 荻野圭三, 山辺潔, 高橋 浩, 油化学, 31 , 290 (1982)

14）日本化学会編, “化学便覧基礎編”, 丸善 (1979) p. 994

15) K. Urano, H. Kano, Bull. Chem. Soc. Jpn., 57, 2051 (1984) 